\title{
SATU GENERASI, TETAPI BERBEDA VISI: PERSEPSI CINTA MENURUT SAFITRI DAN DIKA ONE GENERATION, BUT A DIFFERENT VISION: PERCEPTION OF LOVE ACCORDING SAFITRI AND DIKA
}

\author{
Saksono Prijanto \\ Agency for Development and Language Cultivation \\ Pos-el: saksonorasamala@gmail.com \\ Telepon: (021) 7309234
}

\begin{abstract}
Product types literary readings also increasingly spectacular. They now deliver "literature" is no longer bound by the need to obey the grip to reveal the "beauty" literal. World some resaults laden with poverty, contempt, and the impossibility of them express the voice of freedom. The article "One generation, but a different vision: Perceptions of Love According Safitri and Dika" is written with the intention to try to reconstruct the way of thinking of the leaders in addressing and and deal with various aspects of life they experience, especially about the romance that unfolds in the novel Kelir Slindet works Kedung Darma Romansha and Koala Kumal, Marmut Merah Jambu, dan Cinta Brontosaurus work Raditya Dika.In order to get a complete picture of the literary works of two writers will be disclosed meaning behind the actions of the characters, particularly in negotiating the turmoil of life. Efforts disclosure as well reconstruction their thinking in negotiating the various aspects of life that used semiotic approach. Through the paradigmatic relationship patterns, is patterns between characters relationships with other characters and patterns between characters relationship with the community is expected that work becomes clear legibility.
\end{abstract}

Keywords: reconstruction, semiotic, paradigmatic

\begin{abstract}
ABSTRAK
Produk bacaan jenis sastra sekarang semakin spektakuler. Mereka sekarang menyampaikan "sastra" tidak lagi terikat dengan keharusan untuk taat kepada pakem dengan mengungkapkan "keindahan" secara literer. Dunia jungkir balik yang sarat dengan kepapaan, kenistaan, dan kemustahilan mereka ungkapkan dengan suara kebebasan. Artikel "Satu Generasi, tetapi berbedavisi: Persepsi Cinta Menurut Safitri dan Dika" ditulis dengan maksud untuk mencoba merekonstruksi cara berpikir para tokoh dalam menyikapi dan dan menyiasati beragam aspek kehidupan yang mereka alami, khususnya tentang percintaan yang terungkap dalam novel Kelir Slindet karya Kedung Darma Romansha serta Koala Kumal, Marmut Merah Jambu, dan Cinta Brontosaurus karya Raditya Dika.Untuk dapat memperoleh gambaran utuh mengenai karya dua sastrawan itu akan diungkapan makna di balik tindakan para tokoh, khususnya dalam menyiasati gejolak kehidupan. Upaya pengungkapan sekaligus perekonstruksian cara berpikir mereka dalam menyiasati beragam aspek kehidupan itu digunakan melalui pendekatan semiotik. Melalui pola hubungan paradigmatik, yaitu pola hubungan antartokoh dengan tokoh lain dan pola hubungan antartokoh dengan masyarakat diharapkan keterbacaan karya tersebut menjadi jelas.
\end{abstract}


Kata kunci: rekonstruksi, semiotic, paradigmatik PENDAHULUAN

Sastra adalah kristalisasi keyakinan, nilai-nilai, dan norma-norma yang disepakati masyarakat-setidaknya begitulah yang terjadi di zaman lampau ketika kepengarangan tidak dimasalahkan dan berbagai jenis tradisi lisan dimiliki beramairamai oleh masyarakat, tidak oleh individu. Pada waktu itu produksi, penyebarluasan, konsumen boleh dikatakan merupakan non-issue, hal yang tak perlu digunjingkan karena berlangsung begitu saja. Pada waktu itu pula dengan, demikian, apresiasi sastra dalam pengertian kita sekarang ini tidak pernah terpikirkan. Berbagai jenis pengungkapan pengalaman dan penghayatan manusia disampaikan oleh nenek di tempat tidur, pawang dalam suasana ritual, dan pemuka masyarakat dalam berbagai jenis upacara. Tidak peduli apakah khalayak yang mendengarkan memiliki apresiasi atau tidak-dan pewarisan tradisi yang berupa nilai-nilai dan norma-norma sosial-pun berlangsung begitu saja (Escarpit, 2005:viii).

Telaah dalam artikel ini mengenai novel Kelir Slindert (Kelir Slindet merupakan bagian dari suatu trilogi. Novel kedua berjudul Telembuk (Kisah yang Tak Selesai), sedangkan novel ketiga berjudul Sepenggal Kabar dari Kota Mangga.). Sementara itu, beberapa karya Raditya Dika yang dibahas, antara lain Koala Kumal, Marmut Merah Jambu, Cinta Brontosaurus. Karena objek penelitian membahas karya dari dua orang pengarang, metode perbandingan digunakan untuk penulisan artikel ini seperti halnya memerikan dan menguraikan (Damono, 2005:2). Sementara itu, dalam telaah sastra bandingan faktor masyarakat dan tata nilai sangat penting untuk diperhatikan karena sastra adalah sebagai bagian dari kebudayaan, yang ditentukan antara lain oleh geografi dan sumber daya alam, (Damono, 2005:43). Pendapat tersebut senada dengan pandangan Teeuw (2013:78-79) yang menegaskan bahwa pemahaman sebuah karya sastra tidak mungkin tanpa pengetahuan, sedikit banyaknya, mengenai kebudayaan yang melatarbelakangi karya sastra tersebut dan tidak langsung terungkap dalam sistem tanda bahasanya. Untuk memahami beberapa sajak Soebagio Sastrowardojo tidak dapat kita pahami dengan baik tanpa pengetahuan mengenai wayang, dan peranan wayang dengan baik tanpa pengetahuan mengenai wayang dan peranan wayang dalam kebudayaan Indonesia, termasuk pengetahuan apakah kayon dan dalang

Objek telaah dalam penulisan artikel ini adalah genre sastra novel. Dalam genre itu beberapa aspek perlu dicermati, yaitu perkembangan satu karakter, situasi sosial yang rumit, hubungan yang melibatkan banyak atau sedikit karakter, dan berbagai peristiwa ruwet yang terjadi beberapa tahun silam secara lebih mendetil (Stanton, 2012:90). Berkaitan dengan itu, Wellek (2014:27) menyatakan bahwa salah satu nilai kognitif novel adalah segi psikologisnya. "Novelis dapat mengajarkan lebih banyak tentang sifat-sifat manusia daripada psikolog".

Ini adalah pernyataan yang sering kita dengar. Karen Horney menunjuk pada Dostoevsky, Shakespeare, Ibsen, dan Balzac sebagai sumber studi psikologi. E.M. Forster (Aspcct of the Novel) mengatakan bahwa sedikit sekali orang yang kita kenal 
jalan pikiran dan motivasinya. Oleh karena itu, novel sangat berjasa mengungkapkan kehidupan batin tokoh-tokohnya.

Beberapa hal yang perlu dicermati dalam telaah sebuah karya fiksi, khususnya sebuah novel antara lain judul, karakter tokoh, sudut pandang, latar belakang budaya yang mendasari penciptaan karya tersebut. Kita mengira bahwa judul selalu relevan terhadap karya yang diampunya sehingga keduanya membentuk satu kesatuan. Akan tetapi, penting bagi kita untuk selalu waspada apabila judul tersebut mengacu pada satu detail yang tidak menonjol. Judul semacam ini acap (terutama sekali dalam cerita rekaan menjadi petunjuk makna cerita bersangkutan (Stanton, 2012:51).

\section{METODE PENELITIAN}

Menurut Nazir (1985:52), metode berkaitan erat dengan cara yang ditempuh, meliputi berbagai tahap pelaksanaan pembahasan dan berbagai jenis alat yang digunakan. Hassan dan Koentjaraningrat, (1985:7--8) menyatakan bahwa metode merupakan cara kerja untuk memahami objek yang menjadi sasaran ilmu yang bersangkutan. Sebagaimana telah dikemukakan pada bagian yang terdahulu, tujuan pembahasan adalah merekonstruksi novel Kelir Slindet serta Koala Kumal, Marmut Merah Jambu, Cinta Brontosaurus secara sistematis dan menemukan gagasan utama yang terkandung di dalamnya. Dalam hal ini, struktur karya sastra tersebut dianggap sebagai tanda sehingga di dalam pembahasan ini digunakan metode (pendekatan) semiotik. Sesuai dengan objek yang dibahas, teknik pembahasan yang digunakan adalah teknik pembahasan studi pustaka.

Metodologi yang digunakan dalam penulisan artikel ini adalah metode kualitatif yang meliputi metode penentuan percontoh (sampel) dan bagaimana menganalisis percontoh tersebut. Metode kualitatif terkait dengan interpretasi dan pemahaman. Metode kualitatif memanfaatkan cara penafsiran dengan menyajikannya dalam bentuk deskripsi. Metode kualitatif memberikan perhatian terhadap data alamiah, data dalam hubungannya dengan konteks keberadaannya. Cara inilah yang mendorong metode kualitatif dianggap sebagai multimetode sebab penelitian pada gilirannya melibatkan sejumlah besar gejala sosial di tempat pengarang berada, termasuk unsur kebudayaan pada umumnya (Ratna, 2011:39--47). Metode semiotik digolongkan sebagai metode kualitatif. Sementara itu, landasan berpikir metode kualitatif adalah paradigma positivisme Max Weber, Immanuel Kant, dan Wilhelm Dilthey. Dengan demikian, objek penelitian bukan gejala sosial sebagai bentuk substantive, melainkan makna-makna yang terkandung di balik tindakan, yang justru mendorong timbulnya gejala sosial tersebut (Ratna, 2011:47). Hal itu sesuai dengan tujuan penulisan artikel, yaitu berusaha mengungkap makna karya sastra,yang tentunya tidak dapat dipahami hanya dengan memperhatikan gejala sosial yang tampak di permukaan. Untuk dapat memperoleh gambaran utuh mengenai karya sastra yang dijadikan objek pembahasan, diperlukan pengungkapan makna yang terkandung di balik tindakan yang mendorong timbulnya gejala sosial tersebut. Data 
yang diolah adalah data formal berupa kata-kata, kalimat, dan wacana yang termuat dalam karya sastra tersebut.

Dalam artikel ini sumber data yang ditelaah adalah novel Kelir Slindet (2014) karya Kedung Darma Romansha dan beberapa "novel" karya Raditya Dika, yaitu Koala Kumal (2014), Cinta Brontosaurus (2014), Marmut Merah Jambu (2014). Data tersebut merupakan data formal: terdiri atas kata-kata, kalimat, dan wacana.

\section{HASIL DAN PEMBAHASAN}

\section{1) Kelir Slindet}

Pembahasan terhadap novel Kelir Slindet dapat dilihat dengan jelas melalui pola hubungan paradigmatik, yaitu melalui hubungan Safitri, baik dengan kedua orang tua, teman maupun hubungan percintaan sebagai berikut.

(1) Hubungan antara Safitri dan Kedua Orang Tua

Safitri seorang gadis manis berumur empat belas tahun dan masih duduk di bangku SMP. Akan tetapi, permasalahan hidup yang harus dihadapi remaja putri itu sangat kompleks sehingga gadis muda itu tidak mampu menanggung beban hidup itu. Ibu Safitri bernama Saritem seorang telembuk (pelacur) dan ayahnya, Sukirman (seorang penjudi dan pelanggan cinta di di lokalisasi pelacuran). Orang tua Safitri tidak mampu mendidik anak gadisnya itu supaya berperilaku baik dalam kehidupan. Justru dalam keputusasaan, Safitri cenderung hanyut mengikuti jejak orang tuanya.

Perhatikan kutipan berikut ini ketika Safitri menolak pinangan Mustafa. Ibu Safitri kecewa dan marah kepada putri tunggalnya yang diharapkan menjadi penopang kehidupan masa depan keluarga. Menyikapi reaksi ibunya itu, Safitri melontarkan jawaban dengan enteng dan mudah tanpa beban dan pertimbangan yang masak, sebagai anak yang baik.

"Sampai kapan emak memata-mataiku terus?" "Sampai kamu benar-benar sadar kalau kamu anak dari seorang mantan telembuk miskin dari ayah yang bajingan." Saritem menyolot. "Safitri ingin hidup tanpa beban apa pun, Mak."

"Anak bodoh, kalau kamu menikah dengan Mustafa, semua beban tak ada lagi, Hidup kita makmur, Fit. Emak tidak perlu bercita-cita jadi TKW ke Abar Saudi lagi. Cukup di Cikedung sambil menimang cucu. Kamu lihat bapakmu itu! Hidup tidak jelas. Mengurusi diri sendiri saja tidak bisa, apalagi ngurusi keluarganya. Apa kamu mau punya suami seperti itu? Dengar, Fit, modal cinta saja tidak cukup. Karena uang akan mengubah semuanya, termasuk cinta."

"Jangan bawa masa lalu emak. Kita berbeda. Pikirin terus kemauan Emak, sampai lupa pada anak sendiri!" Safitri masuk ke dalam kamarnya dan menutupnya. Tidak lama ia menyetel lagu tarlingan. (Romansha, 2014/72). 
Kutipan di atas mendeskripsikan percakapan yang tidak sejalan antara emak dan anak gadis yang masih berusia remaja. Gadis belia itu berpikir secara sederhana tanpa bimbingan orang tua dan cenderung keras. Tokoh Emak tidak mampu melunakkan kekerasan hati Safitri yang bertahan ingin mandiri tanpa memikirkan nasib orang tuanya karena dianggap akan membebani hidupnya. Kalau dicermati tampak jelas bagaimana hubungan di antara mereka. Pilihan kata/frase anak bodoh dan kalimat uang akan mengubah semuanya mengisyaratkan bahwa karakter tokoh yang mengucapkan kurang terdidik dan bersikap materialistis terhadap kehidupan. Safitri meyakini bahwa di hadapan Mustafa kedua orang tua Safitri itu justru akan mengganggu hubungan mereka. Kehidupan kelam orang tua itu akan membekas bak racun secara kejiwaan. Safitri belum mampu membuka hatinya untuk menerima secara dengan tulus dan ikhlas mengenai latar belakang orang tuanya yang dianggapnya memalukan. Sebaiknya, karakter Safitri lebih pragmatis karena Dia menyadari siapa dirinya dan bagaimana masa lalu kehidupan kedua orang tuanya. Semakin ibunya mendesak agar dirinya menerima lamaran pemuda itu, Safitri semakin semakin menolak untuk menikah dengan Mustafa. Suasana hubungan antara Safitri dan emaknya semakin meruncing dan konfilk itu sudah dapat ditebak bahwa mereka akan bersimpangan jalan. Sebagai alasan atas penolakkan itu Safitri menyatakan untuk dirinya dan orang tuanya bahwa dirinya lebih mencintai Mukimin, adik Mustafa yang masih seumur dengan Safitri. Mukimin yang tergolong "berandal" itu justru memiliki daya tarik dan meyakinkan bagi Safitri untuk mengarungi kehidupan berumah tangga. Kepasrahan terhadap takdir melekat kental pada tokoh Safitri. Baginya Mukimin lebih realistis sebagai calon suaminya daripada Mustafa yang dalam pandangan Safitri berada di atas menara gading. Sementara itu pendapat negatif terhadap putusan dan sikap Safitri datang bertubi-tubi dengan sangat kejam.

\section{(2) Hubungan antara Safitri dengan Teman-temannya}

Pola hubungan antara Safitri dengan teman-temannya cenderung identik dengan pola hubungan percintaan Safitri. Mustafa, Mukimin, Didik, dan beberapa pemuda sebaya Mustafa, seperti Taufik Hidayat, Safrudin, Mereka adalah teman sekampung dengan Safitri. Beberapa di antara mereka aktif di pengajian dan kasidah. Fitri akrab dengan mereka di lingkungan tersebut. Akan tetapi, tidak dapat dipungkiri bahwa perhatian "khusus" para pemuda itu karena kecantikan paras Safitri. Kecantikan Safitri menyebabkan beberapa pemuda mencoba menjalin hubungan dengan gadis itu. Mereka itu adalah Mustafa, Mukimin, Didik, dan Safrudin. Didik berupaya keras ingin mengangkat martabat Safitri. Tokoh Didik sangat tidak percaya akan pembicaraan buruk tentang Safitri dan kedua orang tuanya. Didik menganggap bahwa orang di sekitarnya hanya merasa iri akan kecantikkan Safitri sehingga gadis cantik yang hanya anak pelacur itu dianggap tidak layak dinikahi oleh keluarga terhormat, anak seorang haji yang menjabat sebagai kuwu di daerah Cikedung, Indramayu. Beberapa pemuda sebaya Mustafa, seperti Taufik Hidayat, Safrudin, dan Muhimin berupaya keras ingin mengangkat martabat Safitri. Upaya mereka menarik perhatian Safitri melalui "pemartabatan" gagal karena bagi Safitri martabat seorang 
manusia bukan diukur apakah dia beribu seorang pelacur dan sekaligu berbapak penjudi. Dalam obsesi Safitri, kebebasan berpikir dan berani mengambil keputusan merupakan kelayakan seorang manusia.

\section{(3) Hubungan Percintaan Safitri}

Safitri bersahabat dengan pemuda teman satu sekolahnya dulu, yaitu Muhaimin, atau sering dipanggil Mukimin. Remaja itu tidak terlalu tampan, tetapi cukup menarik bagi Safitri sekalipun cara Mukimin untuk menarik perhatian Safitri sangat aneh. Mukimin suka mengintai aktivitas Safitri apabila gadis itu berada di langgar. Sementara itu, Ustad Mustafa seringkali mengajak Safitri yang berwajah cantik dan bersuara merdu itu bergabung dalam kelompok kasidah. Safitri sangat senang menerima ajakan itu, bahkan cenderung merasa bangga. Sikap ustad Mustafa yang menaruh perhatian khusus terhadap Safitri menyebabkan alur cerita menjadi semakin rumit. Safitri tidak mencintai ustad Mustafa dan Safitri khawatir menjalin cinta dengan keluarga seorang Haji sekaligus menjabat sebagai kuwu di daerah itu. Perasaan Safitri terbebani oleh latar belakang ayah dan ibunya yang kelam dan memalukan. Nasib Safitri sebenarnya cukup baik. Banyak peluang bagi Safitri untuk menjalin hubungan dengan para pemuda baik-baik. Mereka ingin mengangkat martabat hidup Safitri. Akan tetapi, faktor usia muda dan ketidakmampuan meniti perjuangan hidup dalam garis kebenaran itu menyebabkan Safitri terlepas dari nasib baik, bahkan terseret ke arah kehidupan yang buruk. Para tetangga di Desa Cikedung ramai menggosipkan perilaku negatif keluarga Safitri terutama perbuatan ibu dan ayah Safitri. Safitri tidak mampu menangkap peluang positif dari para pemuda yang akan mengangkat harkat dan martabat kehidupannya. Tokoh Didik sangat tidak percaya akan pembicaraan buruk tentang Safitri dan kedua orang tuanya. Didik menganggap bahwa orang di sekitarnya hanya merasa iri akan kecantikkan Safitri sehingga gadis cantik yang hanya anak pelacur itu dianggap tidak layak dinikahi oleh keluarga terhormat, anak seorang haji yang menjabat sebagai kuwu di daerah Cikedung, Indramayu. Padahal Safitri dicintai sekaligus oleh dua putra Haji Nasir, yaitu Mustafa dan Muhaimin. Karena memperoleh perhatian khusus dari dua pemuda, kakak beradik itu, Safitri tidak mampu memilih satu di antara mereka dengan akal sehat. Ibu Safitri menghendaki Mustafa menjadi pasangan anak gadisnya itu karena tergolong mapan untuk menopang masa depan Safitri. Namun, Safitri menolak dengan alasan dia tidak mencintai Mustafa. Safitri lebih mengutamakan cintanya kepada Mukimin sekalipun pemuda seumur dirinya itu tergolong anak berandal yang belum jelas masa depannya. Ketidakmampuan Safitri dalam memilih dua pemuda itu yang mengakibatkan dia terbelit oleh kesulitan.

Safitri mencoba bersikap tegas dengan bersedia menjadi istri Mukimin. Dengan menjadi istri Mukimin diharapkan carut-marut kehidupan akan reda. 
Akan tetapi, faktor kemiskinan, baik secara materi maupun sosial seperti menutup niat baik Safitri.

"Lakukan sesuatu, Min! Besok kakakmu akan datang lagi, mungkin esok dia akan melamarku." Safitri mulai tidak sabar.

"Aku bingung," ucap Mukimin datar. Hatinya terus bergemuruh. Sebenarnya dia jengkel pada dirinya sendiri. Mukimin masih terus memandang ke bawah. Sedikit pun ia tak menoleh ke arah Safitri.

"Lihat aku, Min!" Mukimin menatap Safitri begitu dalam.

"Lakukan sesuatu, Min!” Safitri memandang Mukimin dengan harapan yang dalam. Ada semacam kekuatan gaib yang menarik Mukimin lebih dekat dengannya. Tangan kanan Safitri mengusap wajah Mukimin.

Jantung Mukimin semakin berdegup kencang. Memacu seluruh darah dalam tubuhnya. Ia menatap wajah Safitri lama. Matahari di barat tinggal sejengkal saja. Seolaholah mengintip di atas bumi. Warna jingga menempel di dinding langit. Tubuh mereka berdua seperti bayangan hitam, membentuk siluet. Terdengar kumandang azan yang lamat dan jauh. Merayaprayap di sawah dan pohon-pohon mulai gelap

"Aku mencintaimu ..." ucap Mukimin, "pulanglah! Kita ketemu di malam Mapag Sri." Ia beranjak dari duduknya. "Aku tunggu di dekat penabuh gamelan," jawab Safitri. (Romansha, 2014/81).

(4) Hubungan antara keluarga Safitri dan Masyarakat

Masyarakat menuduh Safitri memiliki pamrih menjadi menantu seorang Haji Kuwu, padahal latar kehidupan keluarga orang tua Safitri sangat kelam. Hal itu mengakibatkan konflik dalam keluarga Safitri semakin dipertajam oleh pendapat masyarakat itu. Apalagi ketika mereka mengetahui tentang penolakkan Safitri secara terbuka terhadap Mustafa, guru mengaji dan pelatih kasidah itu. Sebagai orang yang memiliki kelas sosial lebih tinggi, ayah Mustafa, Haji Nasir, tersinggung sehingga memaki Saritem di hadapan tetangga. Akibatnya, tersebarlah berita yang memalukan mengenai masa lalu keluarga Saritem itu. Konflik internal dalam keluarga Safitri berubah menjadi konflik eksternal antara keluarga orang tua Safitri dengan Haji Nasir dan masyarakat. Perhatikan berikut ini ungkapan kata ibu Saritem yang dianggap wanita tidak berpendidikan dan miskin itu.

"Jangan mentang-mentang kamu kaya, bisa seenaknya saja. Kamu pikir aku tidak bisa kaya sepertimu, heh! Kirik! Biar aku miskin tapi tidak nyupang. Sudah berapa tumbal untuk kekayaanmu?! Besok-besok anakmu sendiri yang jadi tumbal untuk kekayaanmu?! Besok-besok anakmu sendiri yang jadi 
korban. Setan! Dasar kaji nyupang!" teriak Saritem dengan sejadi-jadinya. Saritem kalap, emosinya tak bisa dikendalikan.

"Nyebut, Bi, nyebut, Gusti pengeran ...," ucap perempuan tua sambil mengusap-usap bahu Saritem.

"Ingat, Bi, Ingat ...," timpal yang lainnya.

Tak ada yang keluar dari rumah Haji Nasir. Sepi. Tak ada tanda-tanda orang di dalam. Mustafa sendiri masih mengajar di Mts Negeri 1 Terisi. Zaki, masih di pesantren desa Rajasinga dan sudah tak pulang dua bulan. (Romansha, 2014/107)

Ungkapan kemarahan Saritem semakin memperjelas kedudukan sosial wanita itu. Lontaran makian kirik (anak anjing), nyupang (mencari kekayaan secara gaib) yang ditujukan kepada Haji Nasir mempertegas bahwa sosok Saritem tidak berpendidikan sekaligus jauh dari sikap keimanan. Pengontrasan sikap antara Haji Nasir dan Saritem sengaja dipilih narator untuk mengungkapkan bahwa latar belakang sosial masyarakat di daerah itu sangat majemuk. Akan tetapi, narator juga ingin mengungkapkan bahwa persoalan moral manusia tidak dapat dikukur dari kedudukan dan kekayaan seseorang. Saritem merasa malu karena masa silamnya dipergunjingkan para tetangga. Untuk membela diri, Saritem mengungkap peristiwa lampau bahwa Haji Nasir bahwa sebelum berangkat pernah merayu Saritem, tetapi Saritem menolak karena Haji Nasir sudah punya istri dan anak. Celoteh Saritem mengakibatkan nama Haji Nasir tercemar, tetapi Pak Kuwu itu tidak bisa membantah berita itu. Berdasarkan ocehan Saritem itu, sebenarnya Saritem dan Haji Nasir tidak jauh berbeda dalam konteks moralitas.

Persoalan yang menimpa keluarga Safitri semakin menjadi rumit. Beberapa orang tua di tengah masyarakat Cikedung, Indramayu itu mencurigai bahwa Safitri memiliki ilmu "pekasih" yang dapat memikat setiap laki-laki di daerah itu. Sementara itu, di pihak lain, seperti Didik kawan sekolah Safitri, beranggapan bahwa sebagian tetangga Safitri jahil dan tidak suka dengan kecantikkan Safitri. Mereka berusaha mencari kambing hitam dengan menuduh Safitri memiliki ilmu hitam sehingga semakin memperkeruh suasana. Beberapa pemuda sebaya Mustafa, seperti Taufik Hidayat, Safrudin, dan Mukimin berupaya keras ingin mengangkat martabat Safitri. Akan tetapi, belenggu kemiskinan, kebodohan, keimanan dapat diibaratkan sebagai kutukan terhadap Safitri dan masyarakat Cikedung.

Persoalan yang membelit Safitri bukan sekadar kemiskinan dan kebodohan. Ketika Muhidin datang menawarkan sebuah harapan baru bagi Safitri. Muhidin berniat melamar Safitri dan mengajak Safitri untuk bergabung dengan grup kasidah yang baru didirikan seminggu yang lalu. Muhidin datang dengan membawa slindet yang dimasukkan di dalam rantang. Akan tetapi, niat baik ituMuhidin tidak mendapat sambutan dari Safitri. Gadis belia itu tetap memutuskan tidak bersekolah dan bercitacita ingin menjadi penyanyi tarling agar memperoleh uang banyak. "Enakan nyanyi dangdut tarling, banyak duitnya." Safitri menjawab dengan ketus dan malas. 
Muhidin mencoba menuruti keinginan Safitri untuk memiliki uang lebih. Muhidin akan memberi honor Safitri lebih banyak. Hal itu dilakukan Muhidin dengan maksud mengajak Safitri agar kembali bernyanyi kasidah sambil berdakwah. Tanpa ragu Safitri tetap menolak dengan alasan kasidah terlalu banyak aturan dan kurang bebas. Safitri menjawan dengan sesuka hati dan dengan nada kesal. Muhidin mundur karena tidak berdaya menghadapi sikap gadis yang kurang terpuji itu.

Kecantikan Safitri semakin memperburuk citra sosok gadis itu. Isu buruk tentang Safitri semakin merebak di Cikedung. Mereka menduga bahwa Safitri memiliki ilmu pekasih yang mampu membuat semua orang jatuh hati kepadanya. Padahal wajar jika seorang gadis cantik digandrungi banyak pemuda. Perhtikan kutipan berikut ini.

Menurut isu yang berkembang, Safitri mempunyai pengasihan yang diturunkan nenek buyutnya. Ada yang mengatakan berupa gaman, misalnya keris atau jimat. Ada juga yang mengatakan ilmu turunan. Ilmu hitam sekelompok dengan $\mathrm{Ki}$ Brambang, Ki Dusta, dan Ki Keong yang menghuni hutan sinang yang berada di sebelah selatan Desa Amis, yang masih satu kecamatan Cikedung (Romansha, 2014/174).

Kabar miring tentang dugaan bahwa Safitri melakukan perbuatan tidak wajar sehingga mampu menarik hati banyak para lelaki dibahas lebih dalam oleh berbagai para orang tua yang berpengaruh di tempat itu. Mereka rata-rata sangat memercayai isu yang belum tentu benar itu.

Safitri berhasil mewujudkan impiannya sebagai penyanyi dangdut tarling dengan bantuan seorang saudara Safitri. Ketika Safitri manggung dan menggoyangkan tubuhnya, penonton gila menyaksikan goyangan Safitri. Sebaliknya, Sukirman yang ikut menyaksikan goyangan anak gadisnya merasa terpukul dan bersedih. Perhatikan kutipan berikut ini ketika para hidung belang ingin ikut menjoget dengan memberi saweran cukup banyak kepada Safitri.

Suara gendang dan goyang maut berpadu di malam yang panas itu. Orang-orang berebut keluar masuk panggung hanya untuk bergoyang dengan Safitri. Serrrrrr. Orang-orang semakin gila dibuatnya. Sekali menyawer orang-orang akan menghabiskan uang sampai 20 ribu. Sementara yang di depan panggung, terlongo-longo melihat Safitri. Bisa sampai lima orang yang berada di atas panggung dan ia harus meladeni kelima orang itu secara bergantian. Menungging atau bergoyang panas di depannya. Yang belum mendapat giliran harus antri menunggu, seperti mengantri sembako gratisan (Romansha, 2014/190). 
Muncul peranyaan apakah mungkin siswa yang belum lulus SMP dan masih berusia belasan tahun telah dipaksa menentukan masa depannya. Menyiasati hal itu, pihak yang paling bertanggung jawab adalah Saritem karena gagal sebagai seorang ibu. Kemiskinan Saritem menyebabkan Safitri dewasa sebelum waktunya. Safitri terpicu keberaniannya untuk bersikap sebagaimana orang dewasa layaknya. Dia seharusnya masih menikmati masa cinta monyet, barmain-main dan bergaul dengan sesaama kawan lain jenis dengan tanpa harus bersikap naif. Kejanggalan juga tersirat dalam sikap Mustafa. Sebagai pria berpendidikan sarjana, meminang anak gadis berumur belasan tahun. Bagaimana mungkin seorang sarjana sastra seperti Mustafa sedangkal itu dalam memahami persoalan yang dialami Safitri. Gambaran secara utuh sejauh mana pergaulan antara Safitri dan Mustafa selama ini kurang terungkap dalam pengaluran. Narator kurang memaparkan kerumitan dalam konteks pergaulan antara Safitri dan Mustafa. Selain berstatus sebagai guru mengaji dan pelatih musik kasidah, apakah Mustafa tidak membina pendidikan mental Safitri di bangku sekolahnya. Mustafa telah melakukan kesalahan atau kekeliruan untuk bersikap bijak sebagai seorang guru agama. Pengaruh cinta buta telah memicu kerumitan dalam cinta segi tiga di antara mereka itu. Unsur lain yang ikut memperumit persoalan adalah perbedaan umur yang mencolok di antara Safitri dan Mustafa. Hal itu mangakibatkan pokok masalah sulit diurai oleh nalar mereka. Akibatnya, ketiga anak muda itu tidak menentu arah masa depan mereka. Hubungan antara Safitri dan Mukimin berjalan dengan terseok-seok tanpa arah. Sementara itu kedua keluarga itu pun bingung harus berbuat apa karena perilaku putra dan putri mereka. Padahal cap buruk tentang keluarga tersebut terlanjur beredar di tengah masyarakat. Kebobrokkan mental berlangsung pada sebagian pergaulan muda mudi masa kini mampu diangkat sebagai bahan untuk membina mental para remaja. Sepanjang cerita tidak ditemukan deskripsi tentang doa yang terucap oleh Saritem Tuhan sehingga wajar jika Safitri tipikal tokoh pipih, tidak mengalami perkembangan watak. Bahkan, pemuda yang dicintainya, yaitu Mukimin juga tipikal remaja berandal dan tega menzolimi kakak kandungnya. Paparan mengenai peristiwa itu terungkap ketika Mustafa kembali dari rumah Bi Saritem. Mustafa menghendarai motor yang dirusak oleh Mukimin dan kawan-kawannya.

Sementara di luar rumah, Mukimin dengan cepat memasukkan potongan lidi ke lubang kunci motor kakaknya. Setelah selesai ia pergi menemui temantemannya yang berada di samping rumah Safitri. "Hampir saja," celetuk Mukimin dengan berbisik. "Ssssttt, tenang! Jangan berisik! Kita lihat si anjing botak itu mendorong motornya," potong Kartam. Mukimin dan Kasta menahan ketawa. Mereka bertiga pergi dengan puas dan tidak mau tau apa yang terjadi sesudah itu. "Resiko di tanggung penumpang!" Desis Mukimin sambil berlalu pergi (Romansha, 2014/70). 
Peristiwa dalam kutipan tersebut menunjukkan betapa kejam dan brutal Mukimin terhadap kakak kandungnya. Kenakalan para remaja itu telah menjurus pada tindak kejahatan yang tidak dapat dimaafkan. Sudah jatuh tertimpa tangga pula. Mustafa selain ditolak cintanya oleh Safitri, juga harus mendorong sepeda motor karena dirusak oleh Mukimin. Alasan mengapa Mukimin melakukan hal itu sangat jelas. Mukimin bertanggapan bahwa Mustafa bermaksud merebut kekasihnya. Padahal Mustafa terkesan tidak memahami sebegitu dalam cinta Safitri kepada Mukimin. Tipikal pemuda yang seperti itu justru yang dipuja oleh Safitri. Kenakalan remaja tersebut selayaknya menjadi perhatian dan pembinaan yang serius oleh guru di sekolah dan orang tua di rumah. Mereka tidak cukup dengan sekadar nasihat, tetapi memerlukan contoh konkret atau teladan langsung dari orang tua kepada anaknya. Contoh baik dan perilaku benar dari orang tua secara langsung akan membentuk sikap dan mental anak. Menyikapi perilaku menyimpang seperti yang dilakukan Mukimin, setiap keluarga selayaknya menyediakan lahan bersih dan benar bagi pertumbuhan jiwa anaknya kelak.

Dengan cara menjadi sri panggung, Safitri dengan Ratini bekerja keras mencari nafkah yang menurut mereka halal. Safitri berhasil memperoleh uang cukup banyak. Pada suatu waktu Mukimin bersama dua orang kawannya lewat di tempat pertunjukkan itu. Akan tetapi, Mukimin tidak berani menonton kekasihnya yang sedang menjoget di atas panggung. Mukimin memilih pergi meninggalkan keramaian itu. Sementara itu beberapa waktu kemudian, Sukirman memperoleh informasi dari Kaji Caca bahwa Saftri hamil cukup besar. Masyarakat daerah Cikedung menjadi heboh mengetahui Safitri hamil. Safitri tidak ingat siapa lelaki yang sudah datang ke kamarnya sehingga dirinya hamil. Sukirman dan Saritem gelisah. Mereka semakin sediah ketika mengetahui bahwa Safitri telah pergi meninggalkan rumahnya seorang diri. Mereka tidak ada yang mengetahui kemana Safitri pergi dan bersama siapa dia pergi. Mereka mengetahui bahwa Samirin pun menghilang entah ke mana Pada bagian akhir, narator menjelaskan bahwa keberadaan Safiitri dapat dijumpai di berbagai pertunjukkan lagu dangdut tarlingan di daerah Indramayu khususnya di desa Cikedung.

\section{2) Karya Raditya Dika}

Sebuah karya sastra jika sudah diterbitkan maka karya tersebut sudah menjadi milik umum, atau milik pembaca. Meskipun pengarang, Raditya Dika, mengatakan bahwa karyanya bukan sebuah karya sastra, tetapi sebagian pembaca saya mengatakan bahwa karya Raditya Dika sebagai sebuah karya sastra karena faktor intrinsik dan ekstrinsik karya itu sudah terpenuhi, antara lain, dapat ditemukan tokoh, alur, latar, sudut pandang, dan tema serta masyarakat yang melingkupi semua unsur intrinsik itu. Memang, peristiwa dalam karya Raditya Dika itu sebelumnya pernah diupload dalam blog dan sebagian lagi merupakan catatan buku harian. Menengok mundur ke belakang, pada dekade 1950-an, pernah terbit sebuah karya sastra genre novel yang merupakan kumpulan surat-menyurat karya Trisno Sumardjo, yaitu SuratSurat Cinta sehingga karya itu digolongkan sebagai novel epistoler. Dengan 
perbandingan itu, Selain kita mempersoalkan sebuah tulisan sebagai karya satra atau bukan, karya Radika Ditya sangat menarik jika disiasati dari aspek kebahasaan (bahasa sastra)-nya. Dari pengamatan awal, ungkapan bahasa karya Radika Ditya cenderung mengeksploitasi bahasa lisan keseharian, khususnya bahasa yang dipakai anak muda. Bahasa plesetan, trik menghadapi lawan jenis (perempuan), pembaca remaja tidak merasa digurui, trik menghadapi kekecawaan hubungan cinta, bagaimana menghadapi orang tua (sahabat), lucu suka kentut (meniru ayahnya (Batak). Kalau dikerjain/dicemooh lawan jenis, dia semakin pandai karena mencari jalan keluar. Dia maju jika dimotivasi lawan jenis. Berdasarkan pengamatan tersebut, karya Raditya Dika memenuhi syarat sebagai karya sastra karena selain menghibur juga bermanfaat (sumber inspirasi bagaimana hidup dengan patut, baik secara sosial maupun moral) bagi remaja seusianya.

(1) Hubungan antara Dika dengan Kedua Orang Tuanya

Raditya Dika tumbuh menjadi dewasa dalam asuhan keluarga dan pergaulan lingkungan temannya yang mencintai dirinya, baik teman laki-laki maupun perempuan. Sejak kecil dia selalu aktif mencari informasi tentang sesuatu, baik dari masyarakat di sekitar rumah maupun sekolah. Raditya mengaku "Gue adalah orang yang sangat mudah terpengaruh dengan apa pun yang gue lihat, tonton, dan baca." Pengaruh itulah yang menjadikan Raditya sukses di kemudian hari. Perilaku Raditya itu mencerminkan bahwa manusia Indonesia sejak dahulu kala memang termasuk manusia yang mampu membuka diri dan beradaptasi dengan budaya mana pun yang datang menyapanya sehingga bangsa ini menjadi bangsa yang besar dan hebat. Mereka mampu beradaptasi dengan pengaruh dari luar, bagaikan samudra luas membentang untuk menerima pengetahuan apa saja yang datang dari luar.

Sebagai seorang orang yang membesarkan Raditya, ibu Raditya sangat menyayangi putranya sehingga Raditya sering menganggap hal itu sebagai kekangan dari ibunya sehingga merasa kurang mandiri. Raditya yang berjiwa periang, dewasa, mandiri, dan mampu beradaptasi sering terusik oleh kekhawatiran orang tuanya. Namun, seiring berjalannya waktu dan pengalaman, Raditya pun menyadari betapa berartinya sosok seorang ibu baginya . ("Kasih Ibu Sepanjang Belanda" dalam Manusia Setengah Salmon (Dika, 2014/105--33).

Raditya merasa risih atas perlakuan ibunya yang demikian. Sejak di sekolah dasar Raditya atau Dika merasa malu diperlakukan secara berlebihan oleh ibunya. Pada saat berumur 22 tahun, Dika mendapat kesempatan pergi ke Belanda melalui bea siswa guna menghadiri summer course selama dua minggu. Ibu Dika sangat khawatir kepada putranya dengan kepergiannya jauh ke luar negeri. Ibu Dika mempersiapkan pakaian dan makanan Dika secara berlebihan sehingga Dika sangat kesal atas sikap ibunya yang terlalu khawatir terhadap dirinya. Menyikapi respons Dika terhadap ibunya dan kesadaran yang muncul kemudian tentang berartinya sosok ibu, menyiratkan bahwa "Dalam kenyataannya sebagian dari kita masih merasa tenteram 
jika hidup di lingkungan yang selama ini telah membesarkan kita. Hal ini merupakan pertanda kuat bahwa masyarakat Indonesia pada dasarnya masih berada pada tahap tradisional, atau setidaknya belum sepenuhnya modern, terutama dalam pengertian bersikap terbuka terhadap kebudayaan lain" (Damono, 2009:59).

Dalam kisah “Ada Jangwe Di Kepalaku” dalam novel Koala Kumal (2014) banyak waktu Dika tersedot ketika menulis skenario film berjudul "Brontosaurus" sehingga Dika banyak kehilangan waktu bersama kekasihnya. Sementara itu, Dika kerepotan menghindar dari sutradara yang minta naskah skenario. Untuk mengatasi dua masalah itu, Dika mengundang kekasihnya ke rumah agar bisa membaca dan memberi saran terhadap kekurangan naskah karya Dika. Ayah Dika senang menyaksikan hubungan antara Dika dan kekasihnya serta menyarankan agar mereka lekas menikah. Mendengar saran dan alasan ayah Dika, kekasih Dika tersedak ketika makan. Ayah Dika berkomentar, "Agar titit Dika tidak hanya untuk pipis saja." Saran seronok yang mengejutkan mereka itu justru dipakai Dika untuk menyelipkan adegan skenario yang kurang pada saat itu, yaitu adegan lucu belum disisipkan dalam skenario tersebut. Ketika suting film selesai dan akan ditayangkan, Dika bingung karena ayahnya ingin melihat pemutaran perdana itu. Dika dan pacarnya khawatir ayahnya marah dan tersinggung, "ucapan ayahnya tentang "titit" itu disertakan?" Mereka berharap cemas menanti tanggapan ayahnya. Ternyata, ayahnya yang memang periang dan humoris itu tidak memperdulikan kata yang sensitif itu. Dia malah berkomentar, "Seharusnya Dika melakukan adegan mesra, berciuma ketika berada di pom bensin sehingga tampak romantis. Ayah Dika memberi kritik yang membangun. Dika tersenyum lega karena masalah kata "titit" tidak dipersoalkan oleh ayahnya.

Peristiwa tersebut menunjukkan hubungan harmonis dalam orang tua keluarga Raditya sehingga remaja itu dapat tumbuh dengan baik dan sehat jasmani maupun rohani. Raditya senantiasa mendapat perhatian dan dukungan orang tuanya sehingga cita-citanya dapat berkembang dan mengalir lancar. Satu hal yang menjadikan Raditya mendapat tantangan ialah apabila dia sedang jatuh cinta kepada wanita. Dia akan banyak berkorban dan melakukan penyesuaian semaksimal mungkin sekalipun dia harus bersusah payah. Kisah itu terpapar dalam cerita berjudul "Balada Lelaki Tomboi” dalam novel Koala Kumal (Dika, 2014:45--68).

(2) Hubungan antara Dika dengan Teman-Temannya

Orang tua Raditya Dika khawatir melihat pergaulan Dika dengan kawankawannya. Dika terksan kurang senang bergaul dengan teman-teman di lingkunganya karena keadaan fisiknya kurang ideal dan proporsional. Tubuhnya kurus dan pendek sehingga Dika kurang percaya diri berada di antara kawankawannya itu. Dalam kesehariannya, Dika lebih banyak bermain vidio game di kamar. Ayahnya berupaya mengajak Dika bermain layang-layang di dekat jalan tempat orang bermain layang-layang. Usaha ayah Dika berhasil, Dika memperoleh dua orang kawan karib bernama Bahri dan Dodo. Untuk mengambil hati kawan Dika, ibu Dika menyediakan berbagai makanan ringan agar Dika dan kawan-kawannya betah berada di rumah. Ayah Dika memberikan kaus seragam 
untuk Dika dan kawannya sehingga terjadilah keakraban di antara mereka. Dika dan kawannya bermain sepeda, petakumpet, berenang bersama, dan bermain petasan/jangwe. Pelopor permainan itu Bahri dan uang mereka habis untuk membeli barang petasan. Mereka tidak melakukan salat teraweh dengan tenang. Sebelum salat Teraweh selesai mereka bersembunyi di pinggir jalan untuk memasang jangwe dan petasan guna mengganggu para pejalan kaki. Para wanita yang lewat merasa takut. Karena protes tetangga Dika dan Dodo memutuskan untuk berhenti bermain dengan Bahri. Suatu ketika tangan Bahri luka terbakar petasan yang dinyalakan sendiri. Persahabatan mereka renggan karena peristiwa petasan itu. Namun, ibu Dika tidak mengetahui kenakalan Dika dan kawankawannya itu.

Di balik kesenangan yang dialami Raditya dalam berkawan, terdapat juga pengaruh buruk yang dan menyesatkan baginya. Pengaruh buruk tentang petasan itu apabila diketahui orang tua Raditya pasti akan mencemaskan mereka. Beruntung Dika anak cerdas dan dewasa meskipun masih kanak-kanak. Upaya Bahri untuk bertahan bermain petasan tidak berhasil mempengaruhinya, karena Dika dan Dodo kembali bermain layangan seperti semula. Kegiatan selanjutnya setelah dewasa, Dika berkawan karib bahkan menjalin hubungan cinta dengan seorang wanita yang mau mengerti keberadaan Dika. Wanita itu tidak keberatan berkunjung ke rumah Dika yang sedang sibuk mengejar "deadline". Suasana di rumah Dika sangat menyenangkan. Kedua orang tuanya mendukung hubungan antara Dika dan kekasihnya, bahkan mereka diberi dukungan agar segera menikah. Perhatikan kisahnya berikut ini.

Justru pelajaran hidup bagaimana selayaknya seorang anak menghargai ibunya diperoleh Dika di Belanda. Di negeri Belanda Dika berkawan dengan Perek, seorang pemuda berasal dari Praha. Kawan Dika itu yang mengingatkan agar Dika selalu melakukan kontak dengan ibunya melalui "hapenya" yang selalu diabaikan oleh Dika. Perek bercerita bahwa ibunya telah meninggal dunia sejak dia masih kecil. Dia menasihati Dika supaya menyayangi ibunya selagi dia masih ada. Perek yang sudah lama ditinggal ibunya itu sangat rindu kepada ibunya, tetapi tidak dapat berbuat apa-apa, selain hanya bisa mendoakan ibunya. Mendengar nasihat kawannya, Dika segera menyadari kesalahannya. Sajak itu Dika selalu berkomunikasi dengan baik kepada ibunya. Perhatikan kutipan berikut setelah Dika menyadari kekeliruannya (dalam Manusia Setengah Salmon). Seharusnya semakin tua umur kita, kita tidak semakin ingin mandiri dari orang tua kita. Sebaiknya, semakin bertambah umur kita, semakin kita dekat dengan orang tua kita. Kita gak mungkin selamanya bisa ketemu dengan orangtua. Kemungkinan yang paling besar adalah orang tua kita bakalan lebih dulu pergi dari kita. Orangtua kita bakalan meninggalkan kita, sendirian. Dan kalau hal itu terjadi, sangat tidak mungkin buat buat kita untuk mendengar suara menyebalkan mereka kembali. (Dika, 2014/133) 
Demikian pesan Dika untuk kawan pembaca yang masih punya ibu dan bapak agar selalu berkomunikasi dengan baik dengan orangtua, penuh kasih sayang dan hormat. Satu saran baik yang seharusnya diperhatikan oleh para remaja.

\section{(3) Hubungan Percintaan Dika}

Setelah memahami pola hubungan antara Dika dan kedua orang tuanya berikut ini akan diamati hubungan percintaan Dika, baik di sekolah maupun di rumah. Awal pembicaraan masih seputar perhatian ibu dan ayah Raditya kepada perilaku anaknya dalam bergaul di tengah masyarakat. Pengamatan orang tua Dika ternyata keliru. Dika anak yang cerdas dan sangat berhati-hati dalam bergaul. Dika lebih tertarik berkawan dengan teman wanita karena selalu memberi semangat untuk berubah menjadi lebih baik daripada bergaul dengan kawan pria. Melalui cintanya kepada Deska, gadis tomboy yang hobi berolah raga, Dika gemar berolah raga, olah raga jenis apa saja yang baru dikenalnya, berarti Deska sering dihinggapi rasa bosan. Cinta Dika terhadap Deska beralih kepada gadis lain yang hobi memelihara kucing. Akibatnya, Dika pun menyukainya karena kucing dapat mengusir rasa kesepian. Satu pengalaman baru telah diperoleh dari bekas pacar yang kini menjadi saudaranya itu. Sementara itu, di masa SD, Dika juga sangat menyayangi Viola atau Lia. Oleh karena itu, Dika semakin bersemangat untuk mengubah penampilannya agar tampak lebih dewasa di hadapan Lia. Dika selalu mandi dengan sabun wangi milik ayah dan ibunya, juga minyak rambut dan sampo milik orang tuanya dipakai dengan maksud agar dia dapat berpenampilan lebih baik. Dari beberapa kali hubungan percintaan Dika, tersirat bahwa jalinan kasih bagi Dika adalah pupuk untuk mematangkan diri sekaligus inspirasi dan inovasi menapak karier di kemudian hari kelak.

\section{PENUTUP}

Setelah mencermati objek penelitian, yaitu novel Kelir Slindet dan Kuala Kumal, Marmut Merah Jambu, dan Cinta Brontosaurus dapat disimpulkan beberapa hal sebagai berikut.

(1) Latar budaya sangat berpengaruh bagi seseorang ketika orang tersebut harus memutuskan sesuatu, baik dalam kaitan hubungan dengan kedua orang tua, teman maupun masyarakat tempat orang itu besosialisasi.

a) Safitri sebagai seorang gadis belia cukup memiliki pemikiran positif. Dia lebih memilih Mukimin ketimbang memilih Mustafa padahal kedua pemuda itu memiliki hubungan darah langsung, yaitu kakak beradik anak Haji Nasir. Safitri berpikir realistis terhadap perjalanan hidup yang akan dilaluinya kelak. Sebagai tumpuan keluarga Safitri menyadari bahwa dirinya harus bekerja sebagi penyanyi tarling. Profesi itu tidak mungkin dilakukan kalau dia memilih Mustafa sebagai suaminya karena Mustafa berprofesi sebagai guru agama. Sementara itu, kalau memilih Mukimin sebagai suami, Safitri lebih mungkin berprofesi sebagai penyanyi tarling. 
Safitri berupaya mencari harmoni atau keseimbangan dalam kehidupan. Masa silam kedua orang tuanya dianggapnya tidak layak kalau bermenantukan Mustafa yang berpendidikan tinggi dan berprofesi sebagai guru agama.

b) Dika sosok remaja belia yang dibentuk dalam lingkungan sehat dan modern di kota metropolitan Jakarta sebagaimana Safitri juga mencoba mencari identitas diri. Kesempatan yang lebih terbuka bagi Dika dalam segala hal, seperti peluang meraih pendidikan, peluang memilih teman dalam pergaulan, peluang berinovasi dan berkreasi menjadikan Dika lebih bernasib baik dibandingkan Safitri. Dika mampu memfilter berbagai pengaruh yang bersentuhan dengan dirinya, baik pengaruh secara langsung (dari teman-temannya) maupun pengaruh tidak langsung (dari media sosial).

(2) Karakter tokoh memang akan sangat dipengaruhi oleh lingkungan kerluarga yang membentuk karakter tokoh tersebut.

a) Safitri sosok gadis belia yang memiliki keberanian untuk mengatakan tidak kepada Saritem (ibu Safitri) ketika gadis belia itu menolak lamaran Mustafa. Secara finasila mungkin kehidupannya akan lebih baik jika memilih Mustafa sebagai suami. Akan tetapi, Safitri tidak siap untuk terkoyak nuraninya jika kelak muncul konflik antara dirinya dan Mustafa karena masa silam kelam kedua orang tua Safitri.

b) Dika memiliki keberanian dalam wujud yang spesifik dan unik. Karena tidak mungkin bersoialisasi dengan teman laki-laki sebaya, Dika lebih akrab dengan teman perempuan sebaya (Dika sering dibuli teman sebaya laki-laki). Meskipun di kalangan teman sebaya perempuan sering dicemooh, Dika menanggapi cemooh itu sebagai masukan positif dalam rangka pembentukan dan pematangan jati diri.

(3) Pengucapan bahasa dan cara bertutur antara Kedung Darma Romansha dan Raditya Dika sangat berbeda.

a) Kedung Darma Romansha dalam karyanya bertutur secara konvensional. Tahapan bertutur diperhatikan secara runut sehingga pembaca dapat mengikuti sekuen atau urutan peristiwa dengan jelas. Faktor sebab-akibat sangat diperhatikan dengan cermat sebagaimana layaknya cara berkisah pengarang generasi 1920-an. Pemanfaatan simbol masih diperhitungkan dengan baik, seprti pemilihan judul novel Kelir Slindet.

b) Dika bertutur dengan nada yang lazim dipergunakan anak muda generasi sibermetik. Memang, karya Dika merupakan hasil gabungan antara catatan buku harian dan karya blog yang dimuat dalam sosial media. Pemanfaatan gambar dan foto dalam karyanya terinspirasi oleh jalinan kolase, seperti dalam novel karya Budi Darma. 


\section{DAFTAR PUSTAKA}

Damono, Sapardi Djoko. 2005. Pegangan Penelitian Sastra Bandingan. Jakarta: Pusat Bahasa, Departemen Pendidikan Nasional.

---------. 2009. Kebudayaan (Populer) (di Sekitar) Kita. Ciputat: Editum.

Dika, Raditya. 2014. Koala Kumal. Jakarta: Gagas Media.

---------. 2014. Marmut Merah Jambu. Jakarta: Gagas Media

---------. 2014. Cinta Brontosaurus. Jakarta: Gagas Media.

Escarpit, Robert. 2005. Sosiologi Sastra. Diterjemahkan oleh Ida Sundari Husen. Edisi I. Jakarta: Yayasan Obor Indonesia.

Koentjaraningrat. 1983. Mentalitas, Kebudayaan, dan Pembangunan. Jakarta: PT Gramedia.

Miller J. Hillis. 2011. On Literature. Yogyakarta: Jalasutra.

Nazir, Moh. 1985. Metode Penelitian. Jakarta: Ghalia Indonesia.

Ratna, I Nyoman Kutha. 2011. Teori, Metode, dan Teknik.Cetakan 2011. Yogyakarta: Pustaka Pelajar.

Romansha, Kedung Darma. 2014. Kelir Slindet. Cetakan. I. Jakarta: Penerbit PT Gramedia Pustaka Utama, Kompas.

Stanton, Robert. 2012. Teori Fiksi. Cetakan II. Yogyakarta: Pustaka Pelajar.

Teeuw, A. 2013. Sastra dan Ilmu Sastra. Cetakan IV. Jakarta: Pustaka Jaya.

Wellek, Rene dan Austin Warren. 2014. Teori Kesusastraan. Cetakan V. Diterjemahkan oleh Melani Budianta. Jakarta: PT Gramedia Pustaka Utama.

Saksono Prijanto

Semarang, 28 Februari 1954

S1 IKIP Jakarta 1985 Pendidikan Bahasa dan Sastra Indonesia

S2 Ilmu Susastra 1997, Fakultas Ilmu Kebudayaan, Universitas Indonesia 1978 — sekarang bekerja di Badan Pengembangan dan Pembinaan Bahasa 